\title{
Pneumatological Ecclesiology and Its Relationship with Permanent Ecclesiogenesis. Selected Aspects
}

The multifariously motivated turn of ecclesiology to testimonies of the New Testament and to the teaching of the Fathers of the Church, as well as perception of social and cultural determinants of self-understanding, and Church activities allowed to move away from the counter-reformatory, polemically marked understanding of the Church as societas perfecta, i.e., a community that is sufficient for itself, equipped with resources needed to achieve its goals and independent of the state and the world. The newer self-understanding of identity and mission of the Church arises from Christological-pneumatological, historical and sacramental, relational and communal perspectives. A deepened historico-redemptive aspect broadens traditional understanding of the Church's saving ministry as an ongoing and active community in history, and by appreciating the theological, relational, personal and historical character of faith, recognizes the place of creative and actualizing activity of the Spirit in successive generations of believers.

The title issue of pneumatological aspects of permanent ecclesiogenesis is not a competition or opposition to the historical process of establishing the Church by Christ, but by referring to theological specificity of the Church, it broadens

\footnotetext{
${ }^{1}$ Grzegorz Dziewulski, PhD — ordained priest in 1991 in Łódź, defended his doctoral dissertation, Christian testimony as an argument of the Church's credibility (issued in print by RW KUL 2011, ISBN: 978-83-7702-160-6) at the Catholic University of Lublin in 2000; lecturer in fundamental theology and religiology at the diocesan and Franciscan Theological Seminary in Łódź, and at the Theological Institute in Łódź, affiliated to the Pontical Faculty of Theology in Warsaw, also deputy director of that Institute; area of interest: ecclesiology; last publication: Permanent ecclesiogenesis in the perspective of God's Word, Łódzkie Studia Teologiczne 28 (2019) No. 2, pp. 83-97 (also the scientific editor of this issue); e-mail: dziewulski_g@archidiecezja.lodz.pl. ORCID: 0000-0002-6920-4840.
} 
the specificity of its establishment. The manifestations of permanent ecclesiogenesis raised in the text do not include - due to an extensive subject area - all possible, or at least leading ones, as a result of which such aspects as: a reference to the word of God and the liturgy (the role of sacraments, especially the Eucharist and the Church office), the perspective of the reform and renewal of the Church and the idea of Ecclesia in via, the sphere of Tradition, sanctification of the believer and evangelical (Lutheran) ecclesiology, were not raised in the study.

The presentation of the title issue will begin by outlining pneumatological areas of presence and actions of the Spirit in the Church, followed by the presentation of pneumatological places and factors of permanent ecclesiogenesis.

\section{Fundamental nature of presence and activity of the Holy Spirit in the Church}

The continuity that exists between Jesus and His Church is particularly marked in the missionary conclusion of the Gospel of Matthew, and its pneumatological character is most strongly articulated by St. Luke in the 'program' speech of Jesus in the synagogue in Nazareth (Lk 4:16-30), in which He proclaims the fulfillment of Isaiah's announcement (Is 61:1-2). The speech is interpreted in a new way in the announcement of a universal outpouring of the Spirit in the end times (Joel 3:1-5) quoted by Peter (Acts 2:17-21). Both prophecies foreshadowed eschatic restoration of God's people and coming of a new social order, established by the Spirit-anointed prophet (Is 61:1-2; cf. Is 11:1-4), but also by the community into which this Spirit would be poured out (Acts 2:17-21; cf. Is 32:15-18). The final restoration of God's people will be brought about by God Himself through giving the Spirit (Lk 11:13; cf. Acts 2:33). The consequence of this historico-redemptive continuity is identity of the Church as Israel of the end times, i.e., renewed by the paschal mystery of Jesus, canceling out the centuries-old concept of substitution - the substitution of Israel by the Church.

Thus, the event of Pentecost reveals presence of the Church in the world, simultaneously initiating the proclamation of the Gospel 'to the ends of the earth'. In the light of the Acts of the Apostles — in the apostolic testimony in the name, i.e., by the power of Jesus - it is the Spirit that spreads and actualizes the saving work of Christ (Acts 2:21f; 4:12.29-31; 16:18), ensures dynamism and fruitfulness of this preaching, directs and 'cooperates' with disciples, even giving detailed instructions or suggesting decisions (Acts 16:6-7; 20:22.23; 21:4.11). Exalted Kyrios is present and active in communities of the Church 'in' and 'through' the Spirit who communicates and introduces into His prophetic 
mission - after all, the Spirit sent by Him is the same who was and acted in Himself ${ }^{2}$.

Although a Christian experiences Christ as the Spirit (Pneuma) and any experience of the Spirit (Pneuma) is in fact an experience of glorified Christ (2 Cor 3:16-17), They should not be identified or mixed up - the Spirit of the Lord (Pneuma Kyriou) expresses the way of His (the Lord's) existence, i.e., His existence in the divine and eschatological sphere and His action as coming with power to the community. The Spirit given to the Christian remains in such an essential relationship with Christ that, to describe his relationship and life with Him, Paul would be able not to mention the Spirit, but only confess that '...no one, inspired by God's Spirit, can say, "Let Jesus be cursed!" Nor can anyone say without the help of the Holy Spirit, "Jesus is the Lord" (1 Cor 12:3)'. The encounter and knowing Jesus takes place in the Spirit, and He also introduces the baptized person into deeper knowledge and the intimate union, as well as experiencing this unity with Jesus in His body - the Church (LG 683). Such an essential relationship between Christ and the Spirit allows, on the one hand, to attribute effects of Christ and Spirit's activity without distinguishing Them, e.g., Gal 2:17 ('we seek justification in Christ'), and 1 Cor 6:11 ('you were washed, sanctified and justified in the name of our Lord, Jesus Christ and through the Spirit of our God'). Conversely, it allows to join Christ and the Spirit in one statement, e.g., 1 Cor 6:11.12.13.15.45; Rom 1:3-4; 8:11; 9:1, 'I tell the truth in Christ, I do not lie, my conscience confirms it in the Holy Spirit' 3 .

This and such presence of the Spirit in the Church and its mission signifies continuation of historico-redemptive unity of actions of the Spirit and Jesus as Christ (anointed with the Spirit). Jesus' relationship with the Church is not exhausted in the process of its historical establishment, i.e., the role of the Founder since the Gospel of Jesus, His work and fate are constant and life-giving sources of the Church, and the direction of its activities. Jesus Himself - as exalted and glorified Kyrios - who operates in the Church from the beginning and continuously, is its permanent foundation - the foundation in the way of its historical

2 Y. Congar, Wierze w Ducha Świętego. Duch Święty w ,ekonomii”. Objawienie i doświadczenie Ducha, t. 1, thum. A. Paygert, Warszawa 1995, pp. 85-87; M. Wenk, Duch Święty, in: Stownik nauczania Jezusa oraz tematów czterech Ewangelii. Komentarz tematyczny do Nowego Testamentu, t. 1, red. J.B. Green, J.K. Brown, N. Perrin, thum. i red. R. Paprocki, Warszawa 2017, pp. 146-148.

${ }^{3}$ Y. Congar, Wierze ..., t. 1, pp. 80-84. Irenaeus of Lyons would express it in the metaphor of the two hands of God - id., Adversus haereses, IV, 7, 4 (PG 7, 992-993); V, 1, 3 (PG 7, 1123); V, 6, 1 (PG 7, 113); V, 28, 4 (PG 7, 1200). This essential relationship of the Church and the Spirit is significantly reflected in the words of Irenaeus of Lyons, 'where the Church is (ekklessia), there is also the Spirit of God; and where the Spirit of God is, there is the Church and all grace. And the Spirit, it is truth' - idem, Adversus haereses, III, 24, 1 (PG 7, 966). 
initiation, embedding on Him, but also constantly originating from Him. The Spirit sent by Him (Pneuma) is in the Church a constant source of grace and gifts (charisms) for its edification and development. Unity of believers with Christ and the Spirit, initiated in Baptism, is sacramentally actualized, especially through the Eucharist as the Spirit presents Jesus' saving work and introduces into it. The key acts and institutions that lie at the origin and foundations of the Church, such as Baptism, the Eucharist and the apostolic office, are in fact epicletic acts ${ }^{4}$.

An essential element of pneumatological ecclesiology is also the life in the Spirit of those who believed in Christ, beginning with faith and Baptism (Rom 7:6; 8:2). The Spirit (Pneuma) appoints and guides the baptized sons of God (Rom 8:14-17; Gal 4:5-7), so that they should shape their lives 'according to the Spirit' (Gal 5:25), and not 'according to the flesh' (Gal 5:16-17), i.e., the nature spoiled by sin. The advance of the Spirit given to them produces many and manifold fruits (e.g. Gal 5:19-23; 2 Cor 6:6; Rom 6:19-22; 8:6.12f), born in the midst of the struggle between these two ways of life. It is only in the Spirit (Pneuma) that the believer comes into contact with God - in the Spirit the baptized person turns to God, Abba, the Father (Rom 8:14-17), and the Spirit also calls in him/ her in times of weakness (Rom 8:26). Receiving the eschatological gift of the Spirit, however, requires faith (Rom 8:1-2.9; Gal 3:2.5; cf. Eph 1:13-14; 4:30), and recognizing Jesus as the Lord (1 Cor 12:3). The life in Christ and the life of Christ in the baptized have an ecclesial nature (1 Cor 12:13), i.e., the Church is the Body of Christ in a state of constant edification (1 Cor 3:9; Eph 2:20; 4:12), which grows through the Spirit. It is the Spirit, and not other bonds such as kinship, convictions or common goals, that constitute the principle of communion and interaction between God and the baptized (cf. 2 Cor 13:13), preserving freedom and integrity of the interior life in work done ${ }^{5}$.

Among the New Testament forms expressing identity and activities of the Church, the image of the 'body' (Greek: sōma) has a special weight. It is realistic and metaphorical (not allegorical or mystical), and crystallizes the idea of corporate personality. While in 1 Corinthians the emphasis is on organs of the body, i.e., the Church is like a body with many and different organs, in Ephesians the emphasis is on the Head of this Body as the central and directing organ of the body belonging to the heavenly realm. In this Body, individual organs perform various services and functions, including leading, healing, distinguishing between spirits, or also (in their initial form) offices, which are equally valuable gifts of the Spirit for the common good (1 Cor 12:1-10). The union with Christ initiated in Baptism and incorporation into the Church-Body takes place in one Spirit (1 Cor 12:13;

${ }^{4}$ G. Kraus, Die Kirche - Gemeinschaft des Heils: Ekklesiologie im Geist des Zweiten Vatikanischen Konzil, Regensburg 2012, pp. 182-184.

${ }^{5}$ Y. Congar, Wierzę..., t. 1, pp. 70-73. 
cf. Eph 2:18). By the power of gifts (1 Cor 12:7.11), this Spirit is the agent of life and development of the Church-Body, whose dynamism is directed not so much to the service of the world, but to the growth of the Church itself - Christ even fills the Church with His strength and grace (Eph 1:23). This primordial action of the Spirit translates into prior reality of the Body as a whole in relation to individual, concrete believers who become Its, i.e., the Body's organs thanks to mutual love. On the one hand, this metaphor integrates the doctrine of charismatic gifts of the Spirit, and conversely, it reveals the difference between structures of the Church community in relation to the world - these structures emerge from the situation of the Christian as a new, eschatological creature, initiated in Christ, and they are His tools, imbued with the Spirit ${ }^{6}$.

Pneumatological ecclesiology of St. Paul was taken by fathers of the Second Vatican Council. In their teachings, they emphasized the role of the Spirit as animating the divine-human organism of the Church (LG 8), and performing it more in the way of an event (action) than traditional analogy of animating the organism (LG 8). They recalled specificity of the Church as people united by unity of Father, Son and Spirit (LG 4; UR 2), and confirmed the timeliness of charisms as gifts of the Spirit for common benefit and edification (LG 4. 7. 12. 25. 30; AG 4. 23; AA 3). Simultaneously, they emphasized that not only were they instruments of the Spirit, but also social structures of the Church were at the service of the Spirit (LG 8) - the Spirit who constantly actualizes understanding of the Gospel (DV 8,23), prompts us to live according to evangelical counsels (LG 44-45), and awakens apostolic and missionary initiatives (AG 4. 29)7.

The above-outlined multiple activities of the Spirit in the Church are continuation of His cooperation in the mission of Jesus and of God's saving action in the history of mankind. As such, they ensure that the Church preserves its sacramental identity and the mission entrusted to it, its endurance and unity, growth and fruitfulness. Cultural conditions and circumstances of subsequent epochs and centuries in which the Church has to carry out this mission constitute - applying to knowledge of this mission in the light of the Spirit - challenges for shaping adequate and optimal forms of its implementation in the power of this Spirit.

${ }^{6}$ R.Y.K. Funk, Ciało Chrystusa, in: Stownik teologii św. Pawła, red. G.H. Hawthrone, R.P. Martin, D.G. Reid, tłum. zespół, Warszawa 2010, pp. 129-133; P.T. O’Brien, Kościót, in: ibidem, pp. 406-407; R.G. Kratz, Kirche/Gemeinde (K./G.), in: Handbuch theologischer Grundbegriffe zum Alten und Neuen Testament (HGANT), hrsg. v. A. Berlejung, Ch. Frevel, 2015 ${ }^{4}$,

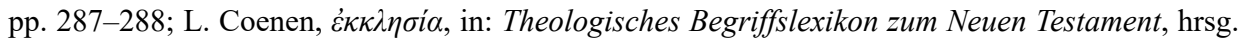
v. L. Coenen, K. Haacker, Witten $2014^{3}$, pp. 1143-1144.

7 Y. Congar, Wierze..., t. 1, pp. 225-234. 


\section{Charisms of the Holy Spirit as means of building a community}

The shape of ecclesial communities presented in St. Paul's writings is characterized by their charismatic order and a local character of leadership. The terminology used by Paul, with a few words defining the authority and organization, suggests that the Apostle did not regard the order in the community as a primary concern. This order was established by participation and charisms, i.e., it was not predetermined by any body, and responsibility for it rested with all who shared the gifts of the Spirit with their fellow man (1 Cor 12:7-11), and discerned His action (1 Cor 14:28.30.32). However, this shape does not mean complete spontaneity, but its functional character ${ }^{8}$.

The basic structure of the community in Corinth was charismatic. The charism (it appears 17 times in the New Testament) is an individual grace, given in a spirit of love for the good of others (1 Cor 12:7), and for building up the community (1 Cor 14:26). The presence of charisms in the community introduces its basic model as a multitude in unity (1 Cor 12:4.11), analogous to the image of the Church as a Body with many organs (1 Cor 12:12f). Spontaneity and free regulations of the fullness of spiritual gifts, which were motivated by the 'service in love', result in their free fluctuation. The lists of apostles, prophets and teachers' services (1 Cor 12:28f) mentioned in the first place indicate their constitutive significance for the community and its service of preaching, implying harmony of the charismatic structure and church office functioning (remaining gifts on the list are individual gifts). The services referred to as ordinances, i.e., leadership (kybérnesis) and headship (but without a cultic element) have a secondary meaning to the primacy of preaching services, but remain irreplaceable, as evidenced by St. Paul to submit to those responsible ones (1 Cor 16:16) .

Charisms, with their universality and diversity, integrally belong to the structure of the Church, as well as to ordinary Christian life, and their biblical 'catalogues' do not exhaust their multiplicity and diversity, after all charisms are also

${ }^{8}$ G. Kraus, Die Kirche..., pp. 81-91. The New Testament presents charisms as gifts of God (e.g. Rom 12:3; 1 Cor 12:28), gifts of Christ (Eph 4:7), or gifts of the Spirit (1 Cor 12:4-11), but generally - because of the most numerous statements linking them to the activity and revelation of the Holy Spirit (1 Cor 12:7) — this perspective dominated their perception.

${ }^{9}$ G. Kraus, Die Kirche..., pp. 64-81. The charismatic service of apostles, witnesses and heralds of the Gospel (traditio, praedicato) guided the activity of prophets and teachers, with the title 'apostle' having a broader meaning: it also means those who received a mission from the Spirit or from the community, e.g. Barnabas in Antioch, and they received the preached message from the Apostles-witnesses. The charism of prophecy is at the service of both preaching and explaining the Gospel, as well as building a community with the help of comforting, and edifying words (1 Cor 14:3). The service of the teacher consisted in methodical, analogous to rabbis, teaching in the scope of the Gospel proclaimed by the Apostles and introducing into Christian behavior. 
founders' charisms underlying religious orders, institutes, associations or renewal movements in the Church. Dynamism, vitality and creativity of charismatic bearers, which translate into new, spontaneous initiatives in the community, are rooted in the Spirit's sovereign action. These initiatives, confronted with the signs of the times, result in more adequate views and methods of communicating faith and salvific mysteries, and stimulate them to accept the gift of salvation. Charismatic vitality of the community is also manifested in the ability to select from among its members competent leaders in the areas of liturgy, teaching and diaconia, without compromising the fundamental, overall coordination on the part of a distinguished leader. The charismatic nature of the community can also be seen in the diaconal character of its structural order, realized in the universal love of neighbour, free from domination and reign ${ }^{10}$.

The source of harmony of the institutional and charismatic element in the community, various services and tasks in the Body of Christ, is their origin in the Spirit and their use in submission to His guidance. Specificity of the Spirit's mission is not only to preserve or renew structures and forms established by Christ since He is the cause and source of what is 'new' in the Body of Christ, and, therefore, also of many innovations derived from charisms. The opinion about rivalry, opposition or antagonism between charisms and institutional activities in the Church is a result of misunderstanding of the 'natural tension' between these two ecclesial elements and dynamisms - after all, the Church office is 'also' an instrument of grace of the Holy Spirit (Acts 6:1-3; 20:28; 1 Ti 1:18; 4:14; $2 \mathrm{Tm} 1: 6-7)$. The use of charisms should be in harmony with hierarchical gifts (LG 4, 7, 11, 12, 25, 30, 50; DV 8; AA 3:4, 30; OP 4:9), especially since without love they lose their value and purpose (1 Cor 13:1-3; cf. Mt 7:22-23) $)^{11}$. Adopting this adversarial approach would destroy complementarity of these spheres in unity of the Body of Christ, while the Church would deprive it of its supernatural dimension, e.g., ordination would only be the transfer of power and functions, liturgical assemblies - one of the forms of social manifestations, and the Church itself would only be an institution focused on worldly goals, torn apart by factional struggles for influence. Leading the Church, which also includes keeping unity, should reflect unity of the Spirit's activity with that of glorified Christ (cf. 2 Cor 3:17; 1 Cor 15:45), for although the Son and the Spirit are separate persons in God, Their activity in the Church does not violate its unity. This unity is

${ }^{10} \mathrm{Cf}$. Kongregacja Nauki Wiary, List Iuvenescit Ecclesia na temat relacji między darami hierarchicznymi a charyzmatycznymi dla życia i misji Kościola (2016), No. 9-12. The same Spirit unites believers in Christ so far that He becomes the principle of the Church's unity (UR 2).

${ }^{11}$ G. Kraus, Die Kirche ..., pp. 92-93; Y. Congar, Wierze ..., t. 1, pp. 76-79; F.A. Sullivan, Duch Święty ,zasada jedności Kościoła” (DE 2), thum. J. Limanówka, ComP 8 (1988) 2, pp. 10-14. 
so far advanced that a Christian experiences both the Son and the Spirit together and may even take One for Another ${ }^{12}$.

The people of God are led not only through sacraments and services, but also - through their participation in the prophetic mission of Christ - with the help of special graces of the Holy Spirit enabling them to undertake activities and functions for renewal, development and intensification of life and mission of the Church (LG 4.12; AA 3). The opposition or separation of charismatic and hierarchical gifts ('Church of the Spirit' and 'institutional-hierarchical Church') violates integrity of economy and history of salvation, as well as coherence of the Incarnate Word's cooperation with the Holy Spirit, whose different missions do not violate their unity. After all, the same Spirit, who participated in Jesus' life and mission is also His gift to the community of believers; the same Spirit - in accordance with the will of Christ and God's saving plan — works through both hierarchical and charismatic gifts, and the same Spirit gives (albeit in different ways) Christ's grace in sacraments and charisms ${ }^{13}$.

Charisms, therefore, which are gifts and signs of the Spirit in the Church, are ordinary, necessary means of its vitality, growth and missionary fruitfulness. Although their use is not free from tensions concerning an ecclesiastical office, integrity of the Spirit's activity in history and preservation of Church's unity are achieved by submitting to the authority of this office and collaborating with it.

\section{Ecclesial communio as the place and goal of the Spirit's activity}

Among many definitions of Church's identity, its goals and specificities, ecclesial communio most intensely focuses on the personalistic character of the Church and forms of mutual relations of its members, which to a lesser extent contain leading biblical metaphors of the People of God, the Body of Christ, the spousal bond of Christ with the Church or the temple of the Holy Spirit ${ }^{14}$. The source, structural and functional foundation, and the model of the ecclesial communio is the Holy

12 Y. Congar, Wierzę w Ducha Świętego. „Panem jest Duch i daje życie” (2 Kor 3,17), t. 2, tłum. L. Rutkowska, Warszawa 1995, pp. 15-22.

13 The dispute over the way the Spirit works in the Church crystallized in the Montanist crisis (Montan, $\uparrow 180$ ), resulting largely from the weakening role of prophets (charisms) in the Church in favour of the authority of the bishop's office: is the true Church one that remains in union with bishops as being the spiritual ones (i.e. bearers of the Spirit) by the power of apostolic succession and ministering or the true Church is rather with charismatics as spiritual people (Greek pneumatikoi) because of their inspirations or ecstasies, and thus their claims to be, as it were, reservoirs and mouths of the Spirit?

14 The importance of the category of communio results from its expression of the mystery depth of the Church. A. Czaja defines communio of the Church as '...realization of the original creative communion with God, which found its perfect fulfillment in Jesus Christ and consists 
Trinity community itself. The initiation of Christ's communio with believers and among themselves is baptismal incarnation in Christ, and its center, visible manifestation, means of growth and duration is agape love (Jn 15:1-11), especially the one flowing from the Eucharist. Unity of communio members, in all diversity of services, offices and charisms, is guaranteed by the Holy Spirit, as He instills into the Mystical Body of Christ and maintains the Presence in John's Gospel of repeated announcements of sending the Spirit to 'you' (Jn 14:16), which means that existence and action of ecclesial communio, as realized in the realm of faith, and therefore on a deeper than natural level, is the Spirit's work ${ }^{15}$.

The communion of the human spirit with the Holy Spirit takes place internally as the One who penetrates depths of God Himself (1 Cor 2:10-11), enters into hearts and dwells in them as in a temple (1 Cor $3: 16 ; 6: 19)$. Therefore, as common to God and man, He is the same in the Head of the Church-Body and the same in its members, He is the soul of the ecclesial community and collective body, the source of the Church's life and growth, the 'mediator' of communication with the person and work of Christ, the source of sacraments efficacy (liturgy) and a guarantor of fidelity to God's word (LG 797-798, 809). The Spirit, therefore, carries out God's plan to rebuild unity of the sinner with himself and among people, and leads them to eschatological unity as the final in which 'God will be all in all' (1 Cor 15:28) ${ }^{16}$.

From this perspective, pneumatological ecclesiology was developed by the Catholic dogmatist from Paderborn, H. Mühlen. His concept of the Church as 'One Person in many persons' implies the presence of one person, one and the same Holy Spirit in many persons - in Christ and in the baptized. The Church, therefore, is a historico-redemptive continuation of Jesus' anointing with the Spirit and endowing with Him the mission, grace of the messianic office and grace of His sonification and mission for 'sanctification of His [Jesus'] humanity'. The Holy Spirit is always the Spirit of Christ - Christ sends His Spirit, and the Spirit gives life to the Body of Christ, hence the access of a Christian to Jesus, and through Jesus to the Father is done in the Spirit. Moreover, the Spirit, unifying parts of the Church by the power of sanctifying grace flowing from the Glorified Lord, causes its growth in love for Him, and by the power of the messianic mission given by historical Jesus - as the same one throughout its history - gives the Church its unity in history. The Spirit, as mediating in laying on

in having a share in God's life' - idem, Eklezjologia komunijna - próba określenia wartości i możliwości rozwoju, RT 55 (2008) 7, pp. 6.

${ }^{15}$ Idem, Podstawowe elementy eklezjologii «communio», "Teologia Praktyczna" 3 (2002), pp. 44-58; W. Kasper, Kościót jako wspólnota. Refleksje nad eklezjologiczna idea przewodnia Soboru Watykańskiego II, ComP 34 (1986), pp. 28-42; B. Biela, Struktura eklezjalnej wspólnoty we wspótczesnym nauczaniu Kościoła, SSHT 2 (2011), pp. 529-546.

16 Y. Congar, Wierze..., t. 2, pp. 23-30. 
hands, which precedes the anointing that enables to receive the Gospel (cf. Acts 10:44-48), bestows grace of initial faith that conditions Baptism and introduces, as a mystagogue, into its reality. Despite obscuring the face of the Church by human weakness and sinfulness, it remains a sacrament of the Spirit, that is, it can be recognized (experienced) in its close relationship with its members and in the transmission (tradito) of the office, word and sacrament, also in particular communities with their charismatic gifts. The Church, as a sacrament of the Spirit, means that it remains in His service and that He shapes it to the greatest extent ${ }^{17}$.

The biblical figure of God's people is also a category harmonizing with the process of permanent ecclesiogenesis. Its advantages are: historico-redemptive and communion character, Catholicism, universality, awareness of choice with its mission to the world and its gifts, theological and historical dynamism of orientation towards eschatological fullness, belonging to it by the will of God and a free human decision, community as the optimal and final form of faith, and finally, susceptibility to the sovereign action of the Spirit. However, related shortcomings, such as the difficulty of translating the biblical ho laos (different from Greek ta èthne / Hebrew gojim - foreign nations, pagans), insufficient articulation of the bond with Christ or the integral belonging to Him in the hierarchy place ecclesiogenesis further in relation to communio $^{18}$.

Thus, the communion character of the Church reveals the importance of the Spirit's action for preserving His supernatural character, confirms the reality and importance of the personal and relational (communal) orientation of Baptism and the Eucharist, as well as appropriateness of communio in relation to the historicoredemptive action of God.

${ }^{17}$ Cf. A. Czaja, Jedna osoba $w$ wielu osobach. Pneumatologiczna eklezjologia Heriberta Mühlena, Opole 1997, pp. 139-143, 157, 160, 182-183, 193-199. H. Mühlen (†2006) proposed his pneumatological ecclesiology in a monograph Una Mystica Persona. Die Kirche als das Mysterium der heilsgeschichtlichen Identität des Heiligen Geistes in Christus und den Christen: Eine Person In Vielen Personen, München-Paderborn $1968^{3}$ (and its social and political implications in a publication Kirche wächst von innen: Weg zu einer glaubensgeschichtlich neuen Gestalt der Kirche. Neubestimmung des Verhältnisses von Kirche und Gesellschaft, Paderborn 1996). The above-mentioned doctoral dissertation of A. Czaja Jedna osoba $w$ wielu osobach. Pneumatologiczna eklezjologia Heriberta Mühlena provides a comprehensive and critical presentation of this idea.

18 S. Jaśkiewicz, Eklezjologia ludu Bożego w nurcie II Soboru Watykańskiego, in: Kościót lokalny w Kościele Chrystusa, red. R. Kantor, Kraków 2015, pp. 7-14, 25-32. Cf. C.S. Bartnik, Katolicka dogmatyka, cz. 2, Lublin 2003, pp. 32-39. The return of theology to the biblical figure of the People of God is a consequence of breaking individualism, and return to the communion character of the Church - the people in Christ, the descendant of Abraham, to whose offspring it incorporates Baptism. 


\section{4. 'Vision' as a form of the Holy Spirit's influence in the Church}

The search for and discernment of adequate and optimal ecclesial forms of the Church's mission, in addition to fidelity to the framework and means established by Christ, such as the apostolic office, sacramental gifts or preaching the Gospel $^{19}$, should also be open and receptive to the inspiration of the Spirit. They also include 'visions', i.e. values, needs and goals that have the ecclesial driving force, which underlie new forms of living the Gospel. Recognizing Jesus' historical activity as 'Jesus' movement' allows us to see in it a community of a vision of the world in which disciples called by Him - moved and carried away by His vision of the Kingdom of God - become tools of its realization, around which other followers then gather - similarly moved and drawn by Jesus' vision. The result of such visions-inspirations born of the Spirit are new ecclesial forms, such as religious orders, missionary, charitable, educational, devotional and Church renewal movements and religious associations ${ }^{20}$.

Since the end times have come with Christ, i.e. the messianic times, and with them universal outpouring of the Spirit and the gift of prophecy (Joel 3:1-5),

19 The key vision for the existence, duration, development and fruitfulness of religious work results from its superiority to other life and structural elements of people and communities that must adapt to it and develop according to its design. The role and power of the impact of the vision was revealed by psychosocial research on development and dying out of religious institutions, whose history turns out to be largely analogous to stages of human life: birth — childhood youth - old age. Next four phases: maturity - aristocracy — bureaucracy — death develop four key values that determine dynamics of development or decline of these institutions: vision, community, program and administration. Cf. K. Wons, Rozwój i zamieranie instytutów zakonnych, Kraków 2008, https://opoka.org.pl/biblioteka/T/TS/rozwoj_i_zamieranie_04.html [access: 24.09.2020]. The source for the idea of an inspiring 'vision' was the research of M.F. Saarinen on renewal and revival of Methodist communities in the USA (The Life Cycle of a congregation, Washington 1989) and their application by P.M. Zulehner in the publication by P. Neuner and P.M. Zulehner, Zrozumieć Kościót. Eklezjologia praktyczna (Poznań 2016), cited in this article, and in the form of a pastoral course for lay people focused on discovering their place in the parish, entitled Grundkurs gemeindlichen Glaubens (Düsseldorf 1992).

${ }^{20}$ P. Neuner, P.M. Zulehner, Zrozumieć Kościót..., pp. 187-214. Movements and new communities appear at turning points and crises. Their specificity is not so much a critique of inadequacy of ecclesial structures, but a turning to a personal conversion, experienced in a community that - exceeding solidarity of human efforts - brings about ecclesial communio. J. Ratzinger distinguished (apart from original monasticism) five waves of great spiritual movements in the history of the Church: missionary monasticism $\left(7^{\text {th }}-8^{\text {th }}\right.$ centuries $)$, the Cluny reform movement ( $10^{\text {th }}$ century), the movement of mendicant orders of St. Dominic and St. Francis ( $13^{\text {th }}$ century), evangelization movements of the $15^{\text {th }}$ century (with a significant contribution of the Jesuits), typically missionary (apostolic) and mostly female congregations in the $19^{\text {th }}$ century - idem, Ruchy kościelne i ich miejsce $w$ teologii, thum. Z. Kijas, "PostScriptum" 6 (1998), pp. 22-26. Cf. P. Cordes, „Ducha nie gaście”. Charyzmaty i nowa ewangelizacja, tłum. J. Sobociński, Gorzów Wielkopolski 1990, pp. 11-62. 
believers cannot be denied the possibility of having a vision of God's plans and expectations towards the Church (cf. 1 Cor 12:7), especially concerning their own place in this Church. Visions constitute a spiritual orientation (cf. Mt 2:1-12: Wise Men from the East), they unite and motivate people, set them in motion and stimulate them to grow, also, like prophets such as Amos, they are a critical perspective for assessing the situation and activities. Reconciliation of individual visions with the 'vision of God' enshrined in the word of God, and especially in the Gospel as a record of Jesus' vision and His disciples' community, as well as development of a common vision that overcomes unilateral attitudes and corrects divergent positions, e.g., at the parish or diocese level, is usually carried out in the synodal way. The stage of listening to 'what the Spirit says to the Churches' (Rev $2: 7 ; 3: 13$ ) continues in a discussion that brings with it additional motivation, and watching over faithfulness of the teaching of the Church embodying the vision of projects is a competence and task of ordained pastors, but not without taking into account the voice of the community. Inclusion of the vision as a form of the Spirit's activity corresponds and confirms essential presence of the Church in the sense of believers not so much in the structures of parishes or organizations, but in places where Christ's disciples gather, also outside these structures ${ }^{21}$.

The fundamental vision in case of the Church, like a founding document, is the word of God as the event and reality of Revelation, attested in the Holy Scriptures and transmitted in the living Tradition of the Church. The reception of the word taking place in the Spirit, its - taking into account the signs of the times (cf. Rom 12:2) - specifying actualization and adequate application by the community, becomes also the act and process of the birth of the Church as a reality of faith in the person and community - the Church, whose integral component is also a structural element. The ecclesial affirmation of the vision concerns it as an ordinary, though uneventful, form of the Spirit's activity in God's people the sociological element is derived from it. Inspirational influence of the vision is revealed in the missionary propagation of the Church, in which specification of a generally formulated mission in new conditions and circumstances finds its orientation (direction) in the initial vision. The vision serves as an orientation criterion even in case of ecclesial renewal ${ }^{22}$.

${ }^{21}$ P. Neuner, P.M. Zulehner, Zrozumieć Kościót..., pp. 197-206. It is worth emphasizing that the Church endured persecution and its own failures not so much thanks to the functional structures, but thanks to the faith and love of Christians for Christ.

${ }^{22}$ Ibidem, pp. 191-195. The blurring and waning of the vision initiates the aging phase of organizations and programs born of it. This aging, accompanied by good administration of existing work and stabilization, tends to stagnate, i.e. to displace interiorization of the vision by institutionalizing it (in religious orders it is routinization of the charism). If emerging calls for renewal of the vision are eliminated by mechanisms of bureaucratization and aristocratization, and accumulated goods and works carried out are treated as signs of vitality and dynamism, the inevitable end of 
The vision, therefore, as a specific form of Revelation, is a peculiar relationship of prophecy and a sign of times, characterized by significant causative power, and aimed at renewal of faith and ecclesial community.

\section{Selected manifestations and aspects of the pneumatological dimension of permanent ecclesiogenesis}

Identity of the Church as a community of the divine person of Christ with a man implies a personal experience of faith that results in the decision to establish a community with Him and take the ethos of following Him. A different degree of maturity and intensity of experiencing this bond, not excluding its weakening or even extinction, means that realization of this choice and desire is not closed in a single and finite situation or in a one-off act, but it is a life process with all its consequences. This eventuality and theological nature of faith is - in its indisposition to participants - an integral element of the biblical ekklessia. Its components are, however, also permanent and tangible figures ('institutions'), such as 'places' for gathering (cf. 1 Cor 11:18) and meeting with the Risen One or geographical and historical tangibility of the community in Corinth (1 Cor 1:2; 2 Cor 1:1), in which this ekklēsia 'happens ${ }^{23}$. Such ecclesiality, considering penetration of the historical experience of faith by the man through a divine initiative and action, allows to recognize the form of permanent ecclesiogenesis in this personal process. The ecclesial relationship with Christ is not in fact the result or form of satisfying some mental or social needs (although they also have their own, but a secondary place), but it is acceptance of a given gift (grace), i.e., due to its relational nature it is also a subject of cooperation - not only is it realized in the Church as a community of God's people, but also as the Church. The supernatural character that specifies this bond requires an adequate environment for its experiencing, and it is the Church as a divine-human community, constituted in God's will and in God's word, sacraments, Church offices and services.

The historico-redemptive horizon and context, but also the driving force of permanent ecclesiogenesis, is the existence of the Church in a situation of eschatological tension between 'already' and 'not yet' Kingdom of God ${ }^{24}$, of which it is

work will be like a silent implosion. However, while the existence of individual people ends with imminent death, in the case of an organization it is possible to renew and revive them through renewal of the initial vision.

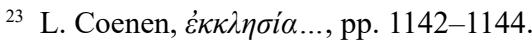

${ }^{24}$ Since Jesus began to teach, heal and call (Lk 17:21: the Kingdom of God is already among you), the Kingdom of God He proclaimed had already begun with Him, therefore, eschatology of the present means the Kingdom of God as a truly effective, though yet hidden reality, present in the world more like a grain than a world storm. Eschatism of this Kingdom has had various interpreta- 
a seed, sign and instrument in history (LG 5; RMis 18). This tension is reflected in eschatological identity of the Church, as well as in its mission and final goal, that is its orientation towards fullness and finality in Eschaton (cf. 1 Jn. 3:1-2). In the New Testament writings, this tension has two forms: according to John the Evangelist, believers in Christ have 'already' had eternal life (Jn 6:29.40.47; 1 Jn. 3:1; 5:11.13), and the Apostle Paul - writing from the perspective of waiting and assurance of God's sonship (Rom 8:19.23-24; Eph 1:14; 1 Tim 6:12; Tit 3:7) simultaneously teaches about the presence of Christ in the baptized ones, advance of the Spirit which strengthens their hope (2 Cor 1:21-22; 5:5; Eph. 1:13-14), and life that has begun in them, which is at the same time the object of its fullness expectation (Rom 8:9-11; 16-23). This tension between 'already' and 'not yet' marking the 'Kingdom of God' of synoptics (and Paul), and John's 'life' opens the Church as a place of the Holy Spirit's activity (Jn 3:3-8; 7:38; 20:19-23). Both the believer's current participation in grace of becoming synonymous and his/her eschatic becoming synonymous have the same source, i.e., they are a gift of the Holy Spirit and the fruit of the Holy Trinity's dwelling in the man - God's own dwelling in His favour for the man, and thus also contributing to his divinization (grace uncreated) and the ontological modification of nature (created, sanctifying grace $)^{25}$.

The mediation of permanent ecclesiogenesis by the Spirit is accomplished by establishing, renewing, and restoring the supernatural bond of faith and by imparting it with supernatural life-giving and fruitfulness. An illustration of this mediation can be found in the Dogmatic Constitution on the Church Lumen Gentium, in which it is expressed in the form of verbs (together with the contexts of their use), with the help of which the relationship between the Spirit and the Church is presented: the Spirit gives life to the dead through the sin (LG 4. 9;

tions in history: although the end times have already begun thanks to the resurrection of Christ (the historico-redemptive 'already'), there is still waiting for all its effects to be realized - the fulfillment of this 'not yet' (eschatology anticipated by O. Cullmann. Other options include consistent eschatology of A. Schweitzer and J. Weiss, realized eschatology of Ch. Dodd, existential eschatology of R. Bultmann and eschatology initiated [within the history of salvation] by J. Jeremias.

${ }^{25}$ Y. Congar, Wierzę..., t. 2, pp. 133-137. P.T. O’Brien, Kościół..., pp. 406-407; J.K. McVay, Glowa, Chrystus jako, in: Stownik teologii św. Pawła, Stownik teologii św. Pawła, red. G.H. Hawthrone, R.P. Martin, D.G. Reid, tłum. zespół, Warszawa 2010, pp. 268-269; R.A. Sikora, Kościót jako Ciało Chrystusa wg Kol i Ef, RT 44 (1997) 1, pp. 131-136. The letters to the Colossians and the Ephesians show presence of tension between 'already' and 'not yet' as lastingly characterizing the growth of the Body-Christ until the Last Day (Eph 4:13), with Christ the Head being the source of the Church's life and growth (Col. 2:19; Eph 1:23; 4:16), and the Church is His fullness (pleroma) (Eph 1:23). This growth is made on the foundation of apostles and prophets, evangelists, shepherds and teachers (Eph 2:20; 4:11-12), and thus, of the tradition and office, and includes coming pagans (Eph 3:6-8). The Church is, therefore, the present heavenly reality and, at the same time, future, eschatological, transforming and renewing reality influencing this world. 
cf. LG 7); the Spirit animates, unites and moves the [Church's] body (LG 7); the Spirit regenerates those who believe in Christ (LG 9); the Spirit causes new people to grow into one (LG 9); the baptized are consecrated by the Spirit (LG 19); the Spirit establishes the sons of God in Baptism (LG 11); the Spirit determines full incorporation into the Church (LG 14); the Spirit enables us to receive the Gospel (LG 19); in the Spirit, God calls new people (LG 26); the Spirit gives power to sacramental signs (LG 59), and gives believers a new life (LG 64). The coming of the Spirit sent by the Son introduces a new relationship between God and the creature, and a new situation of the creature towards God, which is the Church as a community of knowledge and love, truth and grace (cf. Jn 1:14.17) or as the Body of Christ whose life and actions are manifestations of the very life of God. However, while the visible mission of the Son (Incarnation) resulted in unseen goods (graces), the invisible mission of the Spirit is visible through the signs (Greek hos) of wind, dove, fire, speaking in tongues, prophecy, and above all of the Church. The Spirit, therefore, would not so much animate the historical community or institution established by Christ, but created it in the proper sense, i.e. in recognizing the will of Christ not written in the Scripture, such as the canon or form of sacraments, and thus created the Church $^{26}$.

The emergence of new ecclesial forms and realities can take place by transforming what has already existed, e.g., new explications of the word of God and ways of proclaiming and living it, reforming structures and principles of their functioning, actualizing pastoral and liturgical forms. These novelties can also take the form of inspiring and introducing what has not been present in the Church so far or restoring what has expired in the course of its history, such as charisms, permanent diaconate, synodality, the way of presiding over the Church (patriarchates), ways of carrying out missions in new socio-cultural contexts, sensitivity and response to the challenges of time, i.e., bioethics, migration, new ways of communicating and importance of social media. It belongs to the Church shepherds to discern these circumstances, situations or challenges and actions taken in response to them. In the light of the words of God and Tradition read in the Spirit, the Church shepherds study the signs of the times (Latin signa

${ }^{26}$ Defining the Spirit as 'the invisible soul of the Church' (LG 8, 'the social organism of the Church serves the Spirit of Christ which enlivens it'; 'What is our spirit, that is, our soul, for the members of the body, this is the Holy Spirit for the members of Christ, for the Body of Christ, which is the Church' [St Augustine, Sermo 267, 4: PL 38, 1231D]) means His presence in the Head and members of the Mystical Body, which makes it a bond of unity, gives them God's life (fruits of grace and supernatural gifts, and initiates deserving acts of man), supports the Church in teaching the truth of salvation. On co-creating participation of the Spirit in the genesis of the Church in the thought of Y. Congar see A.A. Kasprzak, Pneumatologia w eklezjologii Konstytucji Lumen gentium Soboru Watykańskiego II z perspektywy teologii Yves'a Congara, "Poznańskie Studia Teologiczne" 33 (2018), pp. 41-65 (especially pp. 47, 50, 58-60). 
temporis $)^{27}$, verify news that emerge from them and indicate evangelical directions. However, while acts of ecclesial development and renewal are processes of evolutionary transformation of what has already existed and functioned in the Church, and what due to its insufficiency requires correction, improvement or support while remaining within the range of natural possibilities, the appearance of the process of permanent ecclesiogenesis would be the appearance of what is new and different (original). This novelty — as transcending natural inspirations and commitments, and as a response to various challenges - is confirmed in its clear relationship with the Holy Spirit.

The key importance of personal relationships for identity, way of existence and activity of the Church is revealed in H. Mühlen's view of the Church as 'one Person in many persons', based on identity of the Spirit in the Head and in organs of the Body ${ }^{28}$. It should be emphasized that this approach — by restoring the due, i.e., foreground place for the Spirit as the cause of life and unity of the Church, ecclesiological transmission of the word of God, sacraments and office, or the first mystagogue and builder of the divine-human community - corrects the centuries-old ecclesiological Christomonism. Consequently then, the application of Christ's redemption to humanity involves firstly opening the possibility of salvation by joining Christ's humanity and His historico-redemptive work through the Spirit, and only then - from the revelation of the Church on the day of Pentecost and its lasting presence in history - takes place the application of this salvation by individual, specific people. The Church, therefore, exists as

27 The signs of the times (cf. Rom 12:2; Mt 16:1-4) are contemporary, significant cultural events or processes which, when interpreted in the light of revelation, make it possible to recognize God's plans for humanity, and allow deeper understanding of reality of revelation itself (cf. 11, 44). They owe their popularization in theology to the Bull of John XXIII, Humanae salutis (1961), and his encyclical Pacem in terris (1963), convening the Council. As 'voices of the present day' and hallmarks of the era in the form of, among others, growing importance of the role of workers, presence of women in political life, development of international organizations, and promotion of person's dignity constitute a challenge for the Church's mission, especially in the field of evangelization. The significance of the signs of the times is the result of their expressing actual presence of God and His actions in the history of mankind, thus revealing the image of living and close God.

${ }^{28}$ The Congregation for the Doctrine of the Faith defines the Church as 'the mystery of personal unity of each person with the Trinity and with other people, initiated by faith and directed to the eschatological fullness in the Church of Heaven, which, to some extent, has already been realized in the Church on earth' - List do biskupów Kościoła katolickiego o niektórych aspektach Kościoła pojętego jako komunia „Communionis notio” (1992) No. 1. The signs of this ecclesial communion are discernible in the sphere of experiencing the faith and its external expressions, such as unity of doctrine, sacraments and ecclesiastical guidance (hierarchy) — ibidem, No. 4; LG 25-27. 
communio of the communion of Christ and His believers ${ }^{29}$, established between them and growing in the power of the Spirit ${ }^{30}$.

Continual ecclesiogenesis in believers in Christ, based on the personal nature of Christ's relationship with and between the baptized, essential to identity, action and purpose of the Church, does not interfere with historic establishment of the Church in the process of ecclesiological acts and events taking place within economy and history of salvation. This personal ecclesiality includes, apart from theological dimension of duration and growth in grace, its loss through sin and regaining it, also the existential aspect in the form of a linear-sinusoidal character of experiencing faith, according to life circumstances and commitment, i.e., growth and regression, cessation and restoration of unity with Christ, as well as - in their own way and scope - contemporary social changes related to the Church, such as individualization, privatization, deinstitutionalization, dechurchisation. Losing God's grace (love) as a result of sin, however, does not completely deprive people of belonging to the Church since the key is to have the Spirit of Christ (Rom 8:9; LG 49; cf. Eph 6:14), and this is not only reserved for the perfect and flawless ones. After all, the Church is a community of sanctified

${ }^{29}$ C.S. Bartnik emphasizes that thanks to the Holy Spirit, the Church is presence of the divine Revelator and Redeemer, and therefore, not so much 'something', but 'someone' - 'a kind of person', 'mystical person' (Thomas Aquinas, STh III q. 48 a. 2 ad 1), He is a social Christ, a social person in the Holy Spirit who integrates human persons into His person (pneumatologization of Church members), being in the person of the Holy Spirit. Understood in this way, the Church is made up of prosopoic elements, such as Divine Persons, human persons, communities, acts of communication, personal worlds, and as such, it leads to the communion of Divine Persons as its original source and the Omega point (the Alpha point would be the unity and communion as carriers of the natural dimension). Although the 'body' mediates and conditions the Church in reality of creation ('things'), it 'essentially' does not exist outside of persons - history and matter; Scripture and sacraments are 'only' means, ways, and the language of communication between persons. Ultimately then, the Church is the 'relational modality of the person' and remains at his/her service C.S. Bartnik, Dogmatyka ..., pp. 42-44, 47; idem, Osobowy byt Kościoła, in: Kościót w świetle Biblii, red. J. Szlaga, Lublin 1984, pp. 163-175.

${ }^{30}$ A. Czaja, Jedna osoba ..., pp. 148-149, 188-189. The mediating action of the Holy Spirit either directly identifies Him as 'Mediator', or - limiting mediation only to Christ - expresses the function of the Spirit narratively, which can also be expressed in other categories, such as 'Christlike Spirit' (L.J. Suenens, Kim jest Ona. Synteza mariologii, thum. anon., Warszawa 1988, pp. 124-126), the principle of universalization of Christ's redemption (G. Vass, Die Kirche als Geistwerdung und Person werden der menschlichen Gesellschaft: Eine Auseinandersetzung mit Schleiermachers pneumatologischer Grundformel der Ekklesiologie, ZKTh 100 (1978) 1, pp. 140 177), the Spirit as a continuator of redemptive work, but by making it receive and bear fruit, bringing it to fullness (W. Hryniewicz, Zarys chrześcijańskiej teologii paschalnej, t. 2, Lublin 1987, pp. 63, 103-104). In the opinion of W. Kasper, the acceptance of ontological, absolute, one-of-akind (exclusive) mediation of Christ defines pneumahagic mediation as conditioning and realizing Christ's mediation - the Spirit would be 'the power of Jesus' mediation', 'the personal environment of salvation' (W. Kasper, Jezus Chrystus, thum. B. Białecki, Warszawa 1983, pp. 260-261). 
sinners, constantly invoked and prompted by the Spirit to conversion, penance and return to the union with God. This personal ecclesiality is in harmony with the biblical definition of Christianity as 'the way' (e.g. Acts 9:2; 19:23; 22:4; 24:14.22), with its proper connotations as a direction and goal, the need for a guide and signposts, the possibility of getting lost and off-road, wandering as a result of homelessness, etc. ${ }^{31}$

Intra-ecclesial dynamism of permanent ecclesiogenesis is Catholicism of the Church in its original sense of wholeness and integrity of faith (Greek kath 'holon), i.e., entrusting the Church with fullness of saving goods intended for the entire human race. A manifestation of this dynamism is openness of the Church in its missionary, universal mission, exemplified by inculturation of the Gospel in the Greco-Roman world, Paraguayan reductions and Chinese rites, but also affirmation of local Churches ecclesiality (with all its consequences) or the approval of Church movements and associations from their charisms. This openness comes to the fore in what has been new, unplanned, unpredictable and surprising in life and functioning of the Church so far, and what has been confirmed as fruitful or even necessary only in the future. What is significant here is substantive similarity of biblical expressions of the Spirit with marking the movement factor, such as breath and wind, fire, living water, dove, tongues or attributing the energy of beginning, freedom and openness to the Spirit ${ }^{32}$. This openness is also expressed in sensus fidei (LG 12; 1 Jn. 2:20.26), and sensitivity to the 'signs of the times' that reveal God's plans. In them, social, cultural, communication, economic and other challenges to the Church emerge, to which the response should be new, more appropriate forms of ecclesial activity, such as movements and associations, new ways of understanding and communicating the Gospel or ways of experiencing it, such as the worship of Divine Mercy and the practice of pilgrimage ${ }^{33}$. This openness is directed to the future, which - both in its immediate and final

${ }^{31}$ Cf. Pius XII, Mystici Corporis Christi, No. 22; S. Gręś, Eschatyczny wymiar obecności Ducha Świętego w ziemskim życiu człowieka, in: Duch Odnowiciel, (Kolekcja Communio 12), Poznań 1998, pp. 344-345; G. del Pozo, Chrześcijańskie życie w Duchu i wedlug Ojca, w: Duch Odnowiciel, thum. L. Balter, (Kolekcja Communio 12), Poznań 1998, pp. 220-226, 229-231; A. Nadbrzeżny, Granice Kościoła jako problem hermeneutyczny, in: Koło Naukowe Teologów Katolickiego Uniwersytetu Lubelskiego Jana Pawła II, XLVI Tydzień Eklezjologiczny. Święty Kościót grzesznych ludzi (31 marzec-3 kwiecień 2014 r.), Lublin 2014, pp. 68-71.

${ }^{32}$ It is worth noting that the whole person of Jesus - through His relationship with God as the Son and the Word, and through self-identification as sent from the Father - can be understood as a message, i.e., as a relationship and movement, having a historical expression in being-in-relation-with-Abba and in the unique character of His prayer. As part of them, ecclesiological acts take place, such as choosing the Twelve Disciples, the Last Supper - J. Królikowski, Kościót w Jezusie Chrystusie: Chrystologiczno-pneumatologiczna geneza Kościoła, Kraków 2015, pp. 68, 70-71.

${ }^{33}$ Cf. S. Araszczuk, Język i formy pobożności ludowej, "Seminare. Poszukiwania naukowe" 20 (2004), pp. 163-179. 
realization - belongs to the Spirit. This implies that its newness goes beyond development and improvement of what has already been known in the Church, proven, predictable or verified in its history ${ }^{34}$.

The above outlined thoughts and remarks show the eschatological mission of the Spirit by the glorified Lord and lasting cooperation of this Spirit with the community of disciples in communicating and actualizing Jesus' work as the basis of permanent ecclesiogenesis. The historically established community of the Church remains under the manifold influence of this Spirit in its offices, services and charisms, activities and the interior life of its members. This influence also includes the extraordinary gift of 'vision', which is peculiar unity of the gift of prophecy and the signs of the times. Ecclesial communio as a figure of the community of believers, by its personalistic character, favors articulation of the relational character of faith and sanctification means as the ground for pneumahagic and permanent ecclesiogenesis. It manifests itself in eschatological dynamism of the tension between 'already' and 'not yet' of the Kingdom of God, in the eventdonative and personal character of faith as a communion with Jesus and in its processual experiencing, in the life-giving character and fruitfulness to faith and renewing it, in inspiring and generating new ecclesial realities, clearly exceeding the human potential, in the future-oriented missionary and theological openness, and universality of the Church.

\section{Summary}

The Christological-pneumatological character of post-conciliar ecclesiology, which appreciates the personal-communal (relational), as well as historico-redemptive and eschatological character of the Church, and restores institutional-social dimension of the Church to its proper place in ecclesiology, opens the possibility of extending the traditional approach to the establishment of the Church as a historico-redemptive set of Christ's actions.

Deepened theological reflection on the pneumatological-personal (communio) character of the Church allows us to speak of its permanent personal-pneumahagic process of constant birth in the baptized ones and in the community of faith. Constant presence and influence of the Spirit in the community of the Church and its activities include its offices, evangelizing mission and means of sanctification, but also various gifts (charisms) of the Holy Spirit, as well as development or renewal of the faith life of individual Christians and the community. Aspects of permanent ecclesiogenesis can vary in intensity and form, but they all derive from the influence of the Spirit sent by Christ to His disciples, and are based on the personal, communal, event-oriented (historical) and processual character of faith as communio with Christ and brothers. The forms of permanent ecclesiogenesis can be seen in eschatological Church-directing tension dynamism between

${ }^{34}$ Y. Congar, Wierzę.., t. 2, pp. 34-51; LG 830, 842-843, 832, 851, 868. 
'already' and 'not yet' of the Kingdom of God, in event-donative nature of faith as a communion with Jesus and its processual character, in life-giving character and fruitfulness of faith, in generating new ecclesial realities, clearly beyond human possibilities, in moving towards the missionary future, theological openness, and universality of the Church.

\section{Keywords}

Church, genesis, Christ, Holy Spirit, personalism, renewal, ecclesiology, charisms, communio

\section{Pneumatologiczna eklezjologia i jej związek z permanentną eklezjogenezą. Wybrane aspekty}

\section{Streszczenie}

Chrystologiczno-pneumatologiczny charakter posoborowej eklezjologii, dowartościowujący osobowo-wspólnotowy (relacyjny) i historiozbawczo-eschatologiczny charakter Kościoła oraz przywracający właściwe miejsce w eklezjologii instytucjonalno-społecznościowemu wymiarowi Kościoła otwiera możliwość poszerzenia tradycyjnego ujęcia ustanowienia Kościoła jako historiozbawczego zespołu działań Chrystusa.

Pogłębiona refleksja teologiczna nad pneumatologiczno-osobowym (communio) charakterem Kościoła pozwala mówić o jego permanentnym personalno-pneumahagijnym procesie nieustannego rodzenia się w osobie ochrzczonego i we wspólnocie wiary. Stała obecność i oddziaływanie Ducha we wspólnocie Kościoła i jej działaniach obejmuje urzędy, posłannictwo ewangelizacyjne i środki uświęcenia, ale także różnorakie dary (charyzmaty) Ducha Świętego i rozwój bądź odnowę życia wiary pojedynczych chrześcijan i wspólnoty. Aspekty permanentnej eklezjogenezy mogą mieć różny stopień intensywności i formy, wszystkie one są jednak pochodną oddziaływania Ducha posłanego uczniom przez Chrystusa i bazują na osobowym, komunijnym, wydarzeniowym (historycznym) i procesualnym charakterze wiary jako communio z Chrystusem i braćmi. Postacie permanentnej eklezjogenezy można widzieć w eschatologicznym, ukierunkowującym Kościół dynamizmie napięcia między ,już” a ,jeszcze nie” królestwa Bożego, w wydarzeniowo-donatywnym charakterze wiary jako przeżywanej wspólnoty z Jezusem i jej procesualnym charakterze, w sposobie nadawania życiodajnego charakteru i owocności wierze, w generowaniu nowych rzeczywistości eklezjalnych, wyraźnie przekraczających ludzkie możliwości, w ukierunkowaniu ku przyszłości misyjnej i teologicznej otwartości i uniwersalności Kościoła.

\section{Slowa kluczowe}

Kościół, geneza, Chrystus, Duch Święty, personalizm, odnowa, eklezjologia, charyzmaty, communio 


\section{Abbreviations}

ComP — „Communio”. Międzynarodowy Przegląd Teologiczny (edycja polska), Poznań 1981-

RT - Roczniki Teologiczno-Kanoniczne, Lublin 1948- (od 1991 Roczniki Teologiczne)

SSHT — Śląskie Studia Historyczno-Teologiczne, Katowice 1968-

ZKTh — Zeitschrift für Katholische Theologie, Innsbruck/Wien 1877-

PG - Patrologiae Cursus Completus. Series Graeca I-CLXI, ed. J.P. Migne.

PL - Patrologiae Cursus Completus. Series Latina I-CCXVII, Indices I-IV, ed. J.P. Migne.

RMis - John Paul II, Redemptoris Missio [Encyclical letter] On the Permanent Validity of the Church's Missionary Mandate, 1990.

STh - Thomas Aquinas, The Summa Theologiae I-II (the Summa Theologica) [edycja polska: Suma teologiczna, thum. S. Bełch (i inni), I-XXXIV, Londyn 1962-1986].

AA - Apostolicam actuositatem, Decree on the Apostolate of the Laity, Second Vatican Council, 1965.

AG - Ad gentes, Decree on the Mission Activity of the Church, Second Vatican Council, 1965.

DV - Dei Verbum, Dogmatic Constitution on Divine Revelation. Second Vatican Council, 1965.

LG - Lumen Gentium, Dogmatic Constitution on the Church, Second Vatican Council, 1964.

OP - Optatam totius, the Decree on Priestly Training. Second Vatican Council, 1965.

UR - Unitatis redintegratio, Decree on Ecumenism, Second Vatican Council, 1964.

\section{Bibliography}

Araszczuk S., Język i formy pobożności ludowej, "Seminare. Poszukiwania naukowe” 20 (2004), pp. 163-179.

Bartnik C.S., Dogmatyka katolicka, cz. 2, Lublin 2003.

Bartnik C.S., Osobowy byt Kościoła, in: Kościół w świetle Biblii, red. J. Szlaga, Lublin 1984, pp. 163-175.

Biela B., Struktura eklezjalnej wspólnoty we współczesnym nauczaniu Kościoła, "SSHT 2 (2011), pp. 529-546.

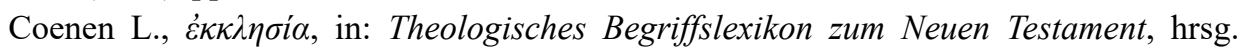
v. L. Coenen, K. Haacker, Witten $2014^{3}$, pp. 1136-1150. 
Congar Y., Wierzę w Ducha Świętego. Duch Święty w ,ekonomii”. Objawienie i doświadczenie Ducha, t. 1, thum. A. Paygert, Warszawa 1995.

Congar Y., Wierzę w Ducha Świętego. „Panem jest Duch i daje życie” (2 Kor 3,17), t. 2, thum. L. Rutkowska, Warszawa 1995.

Cordes P., „Ducha nie gaście”. Chryzmaty i nowa ewangelizacja, tłum. J. Sobociński, Gorzów Wielkopolski 1990.

Czaja A., Eklezjologia komunijna - próba określenia wartości i możliwości rozwoju, RT 55 (2008) 7, pp. 5-15.

Czaja A., Jedna osoba w wielu osobach. Pneumatologiczna eklezjologia Heriberta Mühlena, Opole 1997.

Czaja A., Podstawowe elementy eklezjologii «communio», "Teologia Praktyczna" 3 (2002), pp. 44-58.

Funk R.Y.K., Ciało Chrystusa, in: Słownik teologii św. Pawła, red. G.H. Hawthrone, R.P. Martin, D.G. Reid, tłum. zespół, Warszawa 2010, pp. 129-135.

Gręś S., Eschatyczny wymiar obecności Ducha Świętego w ziemskim życiu człowieka, in: Duch Odnowiciel, (Kolekcja Communio vol. 12), Poznań 1998, pp. 341-354.

Hryniewicz W., Zarys chrześcijańskiej teologii paschalnej, t. 2, Lublin 1987.

Jaśkiewicz S., Eklezjologia ludu Bożego w nurcie II Soboru Watykańskiego, in: Kościót lokalny w Kościele Chrystusa, red. R. Kantor, Kraków 2015, pp. 7-32.

Kasper W., Jezus Chrystus, tłum. B. Białecki, Warszawa 1983.

Kasper W., Kościót jako wspólnota. Refleksje nad eklezjologiczna idea przewodnia Soboru Watykańskiego II, ComP 6 (1986) 4, pp. 28-42.

Kasprzak A.A., Pneumatologia w eklezjologii Konstytucji Lumen gentium Soboru Watykańskiego II z perspektywy teologii Yves'a Congara, "Poznańskie Studia Teologiczne" 33 (2018), pp. 41-65.

Kongregacja Nauki Wiary, List do biskupów Kościoła katolickiego o niektórych aspektach Kościoła pojętego jako komunia „Communionis notio” (1992).

Kongregacja Nauki Wiary, List Iuvenescit Ecclesia na temat relacji między darami hierarchicznymi a charyzmatycznymi dla życia i misji Kościoła (2016).

Kratz R.G., Kirche/Gemeinde (K./G.), in: Handbuch theologischer Grundbegriffe zum Alten und Neuen Testament (HGANT), hrsg. v. A. Berlejung, Ch. Frevel, 20154, pp. 286-289.

Kraus G., Die Kirche - Gemeinschaft des Heils: Ekklesiologie im Geist des Zweiten Vatikanischen Konzil, Regensburg 2012.

Królikowski J., Kościół w Jezusie Chrystusie: Chrystologiczno-pneumatologiczna geneza Kościoła, Kraków 2015.

McVay J.K., Głowa, Chrystus jako, in: Stownik teologii św. Pawła, Słownik teologii św. Pawta, red. G.H. Hawthrone, R.P. Martin, D.G. Reid, tłum. zespół, Warszawa 2010, pp. 268-269. 
Mühlen H., Kirche wächst von innen: Weg zu einer glaubensgeschichtlich neuen Gestalt der Kirche. Neubestimmung des Verhältnisses von Kirche und Gesellschaft, Paderborn 1996.

Mühlen H., Una Mystica Persona. Die Kirche als das Mysterium der heilsgeschichtlichen Identität des Heiligen Geistes in Christus und den Christen: Eine Person In Vielen Personen, München-Paderborn $1968^{3}$.

Nadbrzeżny A., Granice Kościoła jako problem hermeneutyczny, in: Koło Naukowe Teologów Katolickiego Uniwersytetu Lubelskiego Jana Pawła II, XLVI Tydzień Eklezjologiczny. Święty Kościól grzesznych ludzi (31 marzec - 3 kwiecień 2014 r.), Lublin 2014, pp. 64-78.

Neuner P., Zulehner P.M., Zrozumieć Kościót. Eklezjologia praktyczna, tłum. A. Kalbarczyk, Poznań 2016.

O’Brien P.T., Kościót, in: Stownik teologii św. Pawła, red. G.H. Hawthrone, R.P. Martin, D.G. Reid, thum. zespół, Warszawa 2010, pp. 402-410.

Pius XII, Mystici Corporis Christi, encyklika (1943).

Pozo G. del, Chrześcijańskie życie w Duchu i wedtug Ojca, thum. L. Balter, in: Duch Odnowiciel [Kolekcja Communio 12], Poznań 1998, pp. 218-232.

Ratzinger J., Ruchy kościelne i ich miejsce w teologii, thum. Z. Kijas, "PostScriptum" 6 (1998), pp. 8-32.

Saarinen M.F., The Life Cycle of a congregation, Washington 1989.

Sikora R.A., Kościót jako Ciało Chrystusa w Kol i Ef, RT 44 (1997) 1, pp. 129-138.

Sobór Watykański II, Konstytucje. Dekrety. Deklaracje, Poznań 2002.

Suenens L.J., Kim jest Ona. Synteza mariologii, thum. anon., Warszawa 1988.

Sullivan F.A., Duch Święty ,zasada jedności Kościoła”, ComP 8 (1988) 2, pp. 10-14.

Vass G., Die Kirche als Geistwerdung und Person werden der menschlichen Gesellschaft: Eine Auseinandersetzung mit Schleiermachers pneumatologischer Grundformel der Ekklesiologie, ZKTh 100 (1978) 1, pp. 140-177.

Wenk M., Duch Święty, tłum. R. Paprocki, in: Słownik nauczania Jezusa oraz tematów czterech Ewangelii. Komentarz tematyczny do Nowego Testamentu, t. 1, red. J.B. Green, J.K. Brown, N. Perrin, Warszawa 2017, pp. 145-151.

Wons K., Rozwój i zamieranie instytutów zakonnych, Kraków 2008 https://opoka.org.pl/ biblioteka/T/TS/rozwoj_i_zamieranie_04.html.

Zulehner P.M., Grundkurs gemeindlichen Glaubens, Düsseldorf 1992. 